\title{
ISLAH AS THE KEY SUCCESS OF TERRORIST DISENGAGEMENT PROCESS IN INDONESIA
}

\author{
Sapto Priyanto, ${ }^{*}$ Mohammad Kemal Dermawan ${ }^{* *} \&$ Arthur Josias Simon Runturambi ${ }^{* * *}$
}

\begin{abstract}
This study describes about the process of disengagement from terrorists in Indonesia using the Islah, an Islamic method of making a gathering between terrorism victims, terrorists in prison, former convicts of terrorism and their networks in order to build a bridge of communication within them. The activities of Islah consist of various forms such as, gathering with nationalism insight or focus group discussions and building individual friendships. The sincerity of terrorism bomb victims who had forgiven a terrorist before the meeting made the former convicts of terrorism cases feel guilty, and their hearts were touched. They cried and apologized for the actions of their friends and what they had done. Islah allows the disengagement between the victims and the terrorist to happen naturally. This study shows that Islah can be applied in Indonesia as a method of disengagement. Most participants felt sympathetic and apologized to the victims. The friendliness of the facilitator and stakeholders makes Islah more effective. Islah is an effective disengagement method with terrorism victims and perpetrators terrorism from same cases, but Islah is not easy for perpetrators from Poso, Central Sulawesi, because they also consider themselves to be victims. Islah has been part of the local wisdom of the Indonesian people and since the Kingdom of Majapahit era. Islah, as one characteristic Islamic method, is the key to the success of disengagement in Indonesia.
\end{abstract}

Keywords: Disengagement, Indonesia Context, Islah, Terrorism

\section{Introduction}

Data from the Global Terrorism Index shows the reduction of terrorist acts in the world from 2011 to 2019. The decline in the number of terrorist acts in the world is around $12.5 \%$. Data from early 2019 shows the lowest terrorism activity since 2011. The decline in the number of acts of terrorism in the world also cause a decrease the number of deaths due to acts of terrorism. ${ }^{1}$ The number of terrorism acts in Indonesia declined similarly, according to data from Indonesian National Police Chief General Idham Aziz, who cited only eight acts of terrorism in Indonesia in 2019. This number decreases when compared to the number of terrorist acts in 2018 of 19 terrorist acts. ${ }^{2}$ The decline in the number of acts of terrorism in Indonesia shows Indonesia's success in dealing with terrorism. The decline in the number of terrorism act in Indonesia is an interesting topic to explore. The author interested to explore deradicalization programs applied in Indonesia, especially the Islah method.

The Indonesian government's soft approach in dealing with terrorism is deradicalization. According to Director of Deradicalization the Badan Nasional Penanggulangan Terorisme (BNPT) [National Counter Terrorism Agency], "Deradicalization activities which include disengagement carried out by BNPT are activities: assistance, coaching and empowerment". ${ }^{3}$ Besides the BNPT, there are also nongovernmental organizations (NGO) that are using disengagement programs, including the Research Center of Police Science and Terrorism Studies, the School of Strategic and Global Studies, Universitas Indonesia (PRIK-KT UI), ${ }^{4}$ and Aliansi Indonesia Damai (AIDA).

\footnotetext{
* Sapto Priyanto (M. Si) (corresponding author), Doctoral Researcher, Criminology Department, Universitas Indonesia, Depok West Java, Indonesia. Email: saptopriyanto3792@gmail.com.

** Mohammad Kemal Dermawan (PhD), Lecturer, Criminology Department Universitas Indonesia, Depok West Java, Indonesia. Email: mohammadkemaldermawan@gmail.com.

*** Arthur Josias Simon Runturambi (PhD), Lecturer, Criminology Department Universitas Indonesia, Depok West Java, Indonesia. Email: simonrbi@yahoo.com.

${ }^{1}$ Institute for Economics \& Peace (2019), Global Terrorism Index 2019: Measuring the Impact of Terrorism, accessed March 10, 2020, http://visionofhumanity.org/reports.

${ }^{2}$ Bayu Septianto (2019), “Kapolri Klaim Jumlah Aksi Terorisme Sepanjang 2019 Berkurang,” accessed March 7, 2020, https://tirto.id/el1v.

${ }^{3}$ Interview with Deradicalization Director of National Counter Terrorism Agency (BNPT), May 15, 2018.

${ }^{4}$ Previously known as Pusat Riset Ilmu Kepolisian Universitas Indonesia (PRIK UI), since 2017 its name has changed to Pusat Riset Ilmu Kepolisian dan Kajian Terorisme Universitas Indonesia (PRIK KT UI).
} 
One method of disengagement with perpetrators of crimes is restorative justice, namely that which is based on the process of emphasizing the importance of meetings between stakeholders in crimes and afterward. ${ }^{5}$ Restorative process means any process in which perpetrators and victims, or every individual or community member affected by a crime, actively participate in resolving problems arising from the crime, generally with the assistance of a facilitator. Violators of the law, both young people and adults, who are directly responsible to their victims and can be brought together in a facilitated meeting. ${ }^{6,7}$ According to Pavelka, the ultimate goal of restorative justice is to repair the harm caused by the incident while balancing the needs and roles of the victim, offender, and community. Restorative justice is an effort to improve justice through agreement produced by the perpetrators of crimes and their victims. ${ }^{8}$ In restorative justice, the role of crime victims and the community is very important, besides that the direct responsibility of the perpetrators towards the victims can recover their emotions and losses. ${ }^{9,10}$

Restorative justice is one of the values that has existed in Indonesia for a long time and is still used in solving problems. This is written in Kuntara Mawaha, the Majapahit Kingdom legislation in AD 12931500 , that a captured thief can file for forgiveness and release on the condition that he compensates for the release of eight strings, pays a fine of four laksa to the ruling king, and pays compensation loss to affected people (victims) by returning the stolen property twice over. ${ }^{11}$

Restorative justice has existed in Islamic culture since the time of the Prophet Muhammad. There were three human rights violations during Rasullullah SAW that were resolved by Islah, or peace. Those are the disputes over the right to irrigation between Zubair bin Awwâm and an Ansar; acts of murder, illtreatment, and other tyranny committed by Khalid bin Walid and his forces against the inhabitants of the Bani Jadzîmah and Sawad bin Ghaziyyah. The case study of Khalid bin Walid, this is proven by hadith: "The hadith was received from Mahmûd, from 'Abd al-Razzâq, from Ma'mar. Delivered also from Nu'aim, from 'Abdillah, from Ma'mar, from al-Zuhrî, from Slim, from his father who said that The Prophet SAW. sent Khalid bin al-Walid to the Bani Jadzimah and Khalid then charged they are to embrace Islam. The Jadzimah people are not accustomed to saying "aslamna" (we have converted to Islam), then they make the phrase "shaba", shaba "as instead. (Hearing this expression) Khalid killed some of them, charming, and distributing prisoners to each Islamic army. One day later, Khalid ordered Islamic forces killed their respective captives. So, I (the father of Slim) said: "By Allah, I will not kill my captives and neither will my friends will kill their captives. "Until we met the Prophet and deliver the event. Then the Prophet SAW. raising both hands while praying, "O God, I give my hand to you for what Khâlid did. "The phrase is repeated The Prophet SAW. up to two times " (hadith al-Bukhârî, alNasâ' $\hat{1}$, Ahmad, and Ibn Hibbân). ${ }^{12}$ The hadith shows that the method of Islah, or reconciliation or restorative justice, has a special place in the history of Islamic justice for resolving cases of human rights violations. This method proved to be quite successful in resolving cases better and more holistically. Therefore, it is not surprising that peace (Islah) receives a very positive appreciation in Islamic law. ${ }^{13}$

Islamic law allows the settlement of cases through Islah, provided that the cases that are allowed, meet the criteria of justice, do not conflict with syara, and are acceptable to all parties. Islah can only be done in cases of human rights (individuals), such as those involving criminal acts qishas-diyat and civil servants. Allah says in Q.S. al-Baqarah / 2: 178: "O you who believe, it is obliged upon you qishas regarding those who are killed; Free men with free men, servants with servants and women with women. So, whoever gets a forgiveness from his brother, let (those who forgive) follow in a good way, and let (those who are sorry) pay (diat) to those who give forgiveness in a good way (also). That is a relief from your Lord and a blessing. Anyone who exceeds the limit after that, then for him a very painful

\footnotetext{
${ }^{5}$ W. D. Van Ness (2005), An Overview of Restorative Justice Around the World, Centre for Justice \& Reconciliation Prison Fellowship International, pp. $3-4$.

${ }^{6}$ Garry Shewan (2011), Restorative Justice Guidance and Minimums Standards, Association of Chief Police Officers of England, p. 4.

${ }^{7}$ D. Miers (2001), An International Review of Restorative Justice, Crime Reduction Research Series Paper 10, London: Home Office Policing and Reducing Crime Unit Research, Development and Statistics Directorate Clive House, p. 4.

${ }^{8}$ S. Pavelka (2016), "Restorative Justice in the States: An Analysis of Statutory Legislation and Policy," Justice Policy Journal, Vol. 2, no. 13 , p. 6 .

${ }^{9}$ M. S. Umbreit \& T. Lewis (2015), Dialogue-Driven Victim-Offender Mediation Training Manual A Composite Collection of Training Resource Materials, University of Minnesota Center for Restorative Justice \& Peacemaking, pp. 9-10.

${ }^{10}$ T. Wachtel (2013), Defining Restorative, International Institute for Restorative Practices, p. 1.

${ }^{11}$ A. E. Zulfa (2011), "Restorative Justice in Indonesia: Traditional Value," Indonesia Law Review, Vol. 2, no. 1, p. 39.

${ }^{12}$ Ikhwan (2011), "Penyelesaian Kasus Pelanggaran Ham Pada Masa Rasulullah Saw," Miqot, Vol. 35, no. 2, pp. 354-362.

${ }^{13}$ Ikhwan (2011), "Penyelesaian Kasus Pelanggaran Ham Pada Masa Rasulullah Saw,” p. 366.
} 
punishment". ${ }^{14}$ This shows that the principles in Islam regarding qishas law empower victims, perpetrators, and communities. ${ }^{15}$

The key to Islah is forgiveness by the victim. In Islam, forgiveness is one of the morals of those who fear Allah SWT as explained in the Quran Surah Ali Imran verse 134, which describes the attitude of a Muslim who fear that he will face someone who is wrong with him in three ways, namely with holding anger, forgiving, and doing good against anyone who make mistakes with him. ${ }^{16}$ Forgiveness means removing wounds or scars that are in the heart. Islam strongly encourages someone to forgive the mistakes of others. ${ }^{17}$ Giving forgiveness is a virtue, as is asking forgiveness. Forgiveness is a heartchanging decision made by the victim by giving compassion to the perpetrators of crime, in which a person is morally justified to hate. ${ }^{18}$

The previous study about Islah in terrorism cases has not been found by the author. Based on research conducted by INSEP on the motivations and root causes of terrorism in 2011-2012 of 110 terrorists, it was found that there were $87,8 \%$ of Muslim and $12,2 \%$ of non-Muslims. The data shows that the majority of terrorists in Indonesia are Muslims, while other terrorists are non-Muslims. The motive of terrorism in Indonesia is ideological reasons as much as $45.5 \%$, solidarity $20 \%$, mob mentality/friendship $12.7 \%$, revenge $10.9 \%$, situational $9.1 \%$ and separatist motives $1.8 \% .{ }^{19}$ This is the reason why Islah is important to write in terrorism cases. As the author explained in the beginning, the purpose of this study is to determine whether Islah (restorative justice) can be applied to extraordinary crimes of terrorism in Indonesia. Additionally, the authors would like to recommend how the implementation of Islah (restorative justice) has succeeded in making the perpetrators of extraordinary crimes of terrorism realize their mistakes so far and not become a recidivist.

\section{Methodology}

In this study, the authors used a qualitative method by collecting data through secondary and primary sources. The secondary data is obtained through a book entitled Terrorism in Indonesia: Psychological Analysis written by Prof. Sarlito Wirawan Sarwono, the Aliansi Indonesia Damai website, and many kinds of online resources, while primary data through observation is also involved. The observations were made by the author in 2011-2015 in the Program of Empowering da'wah and The Economy to Former Convicts of Terrorism in Indonesia. These activities implemented in Jakarta, Bandung, Semarang, Lamongan, Bandar Lampung, Medan, Ambon, and Poso. This activity was attended by 145 former terrorism convicts and their networks. Additionally, in 2016-2017 was The Entrepreneurship Empowerment Program and Preaching towards Terrorism Prisoners. The activities were implemented in Lapas Cipinang Jakarta, Lapas Salemba Jakarta, Lapas Cibinong Bogor Jawa Barat, Lapas Semarang Jawa Tengah, Lapas Batu dan Lapas Pasir Putih Cilacap Jawa Tengah, and Lapas Madiun dan Lapas Porong Sidoarjo Jawa Timur serta Lapas Makassar Sulawesi Selatan. The total number of participants of this activity was 68 terrorism prisoners. This activity is in collaboration with the Direktorat Jenderal Pemasyarakatan (Ditjenpas).

Moreover, the stakeholders and keynote speaker who will be involved in this activity are required to follow the Trainer of Trainer. The Trainer of Trainer is intended to build the same vision and mission, so that the objectives can be achieved. The materials provided in empowering $d a^{\prime} w a h$ and the economy are (1) deradicalization, (2) psychological aspects of terrorism, (3) religious outreach, (4) community reengagement, (5) conflict resolution, (6) impact of terrorism on innocent bystanders (Islah), and (7) job skill development. The time needed to carry out Islah is $2-3$ hours. Author observations focus on the behaviors and responses of terrorists and networks as terrorism bomb victims introduce themselves, until Islah ends.

\footnotetext{
${ }^{14}$ Ikhwan (2011), "Penyelesaian Kasus Pelanggaran Ham Pada Masa Rasulullah Saw,” p. 367.

Cecep Mustafa (2015), "Restorative Justice and Islam," ResearchGate, accessed March 10, 2020, https://doi.org/10.13140/RG.2.1.3135.6883.

${ }^{16}$ See Moh Khasan (2017), "Perspektif Islam dan Psikologi Tentang Pemaafan," At-Taqaddum, Vol. 9, no. 1, pp. 69-94.

${ }^{17}$ Y. Fitriani \& M. I. Agung (2018), "Islamic Religiosity and Humility with Forgiveness of Students," Psychology Journal, Vol. 14, no. 2, p. 166.

${ }^{18}$ Y. Fitriani \& M. I. Agung (2018), “Islamic Religiosity and Humility with Forgiveness of Students,” p. 134.

${ }^{19}$ A.S. Mufid et al. (2012), Motivation and The Roots Causes of Terrorism in Indonesia, ASEAN and Egypt, Resume Research Report, pp. 4647.
} 
Islam pays attention to the relationship in learning built on the foundation of students' learning and sincere compassion from educators. The process of internalizing values begins with the introduction and reflection of values, the assessment of values, so that in turn they appear in the expression and appreciation of values. Efforts to teach Islamic spiritual values can be said to be successful, if those values are able to become a person's life attitude. ${ }^{20}$ This needs to be understood by everyone involved in carrying out terrorist disengagement in Indonesia.

After we discuss further about Islah, the author will explain the definition of deradicalization. According Horgan, to understand the deradicalization and disengagement, what first needs to be understood is how individuals involved in terrorism are a process. The process starts from joining terror groups, carrying out acts of terror, engaging in acts of terror, or eventually leaving or no longer involved in terrorism, ${ }^{21}$ change in behavior or a person's activity is no longer commit violence and leave the radical group, ${ }^{22,23}$ with various methods are carried out by the government and also the community through a multidisciplinary approach. ${ }^{24}$ Deradicalization is an effort made to reduce the risk of recidivism, reduce one's involvement in the group, and change the recruitment narrative. Deradicalization includes all efforts to change the view that supports violence. ${ }^{25}$ Another expert said deradicalization is defined as part of the perspective of the program's social identity with real success. ${ }^{26}$ Harmoniously Whereas Hoffman argues that the scope of deradicalization lies in terror activities carried out with religious motivation or encouragement. ${ }^{27}$

BNPT defines deradicalization as all efforts to transform radical or ideological beliefs to become nonradical with multidisciplinary and interdisciplinary approaches through identification; rehabilitation; reeducation; and resocialization programs for suspects, inmates, and ex-convicts, their families, and their networks that are indicated radically by promoting the principle of empowerment, human rights, rule of law, and equality. ${ }^{28}$ According to Sumpter, deradicalization by the Indonesian government was seen as insufficient to prevent ex-convicts of terrorism from re-engaging. So, we need a variety of soft approaches that make ex-convicts of terrorism no longer involved. ${ }^{29}$

Horgan and Altier define disengagement as the process of ceasing terrorist activity. Disengagement does not always change ideology or beliefs; it can also be a change in terrorist behavior for the better. Disengagement is distinct from the process of deradicalization, though they are sometimes related. Disengagement can be an individual or a collective process, the decision to disengage may be voluntary or involuntary. ${ }^{30}$ The term disengagement, as stipulated by Horgan refers to "the process whereby an individual experience a change in role or function that is usually associated with a reduction of violent participation., 31,32

The friendship and humanitarian approach are the key to success in the implementation of disengagement of jihadists in Indonesia. ${ }^{33}$ This is in accordance with what was conveyed by Hwang; there are six drivers of disengagement, namely, disappointment with tactics, leadership, or other aspects

\footnotetext{
${ }^{20}$ Nirwani Jumala \& Abubakar (2019), “Internalisasi Nilai-Nilai Spiritual Islami Dalam Kegiatan Pendidikan,” Jurnal Serambi Ilmu, Vol. 20, no. 1 , pp. $166-167$.

${ }^{21}$ John Horgan (2008), "Deradicalization or Disengagement? A Process in Need of Clarity and a Counterterrorism Initiative in Need of Evaluation," Perspectives on Terrorism, Vol. 2, no. 4, pp. 3-8.

${ }^{22}$ Bertjan Doosje et al. (2016), “Terrorism, Radicalization and De-radicalization," Current Opinion in Psychology, Vol. 11, pp. 79-84.

${ }^{23}$ Daniel Koehler \& V. Fiebig (2019), "Knowing What to Do: Academic and Practitioner Understanding of How to Counter Violent Radicalization," Perspectives on Terrorism, Vol. 13, no. 3, pp. 44-57.

${ }^{24}$ Neil Ferguson (2016), "Disengaging from Terrorism: A Northern Irish Experience," Journal for Deradicalization, Vol. 6, no. 1, p. 2.

${ }^{25}$ John Horgan \& M. B. Altier (2012), "The Future of Terrorist De-Radicalization Programs," Conflict \& Security Journal, Vol. 13, no. 2, pp. 84-86.

${ }^{26}$ John Horgan \& K. Braddock (2010), Rehabilitating the Terrorist? Challenges in Assessing the Effectiveness of De-radicalization Program, University Park, Pennsylvania: International Center for Study of Terrorism, Pennsylvania State University, p. 280.

${ }^{27}$ Bruce Hoffman (2009), “A counterterrorism strategy for the Obama administration,” Terrorism and Political Violence, Vol. 21, no. 3, pp. 359-377.

${ }^{28}$ Blueprint Deradicalization (2013), Deputy for Prevention, Protection and Deradicalization of the National Counterterrorism Agency, p. 7.

${ }^{29}$ Cameron Sumpter, K. Y. Wardhani \& S. Priyanto (2019), Testing Transitions: Extremist Prisoners Re-Entering Indonesian Society, New York: Routledge, p. 6.

${ }^{30}$ Cameron Sumpter, K. Y. Wardhani \& S. Priyanto (2019), Testing Transitions, p. 6; John Horgan \& M. B. Altier (2012), "The Future of Terrorist De-Radicalization Programs," pp. 84-86.

${ }^{31}$ John Horgan (2009), Walking Away from Terrorism: Accounts of Disengagement from Radical and Extremist Movements, New York: Routledge, p. 152.

32 John Horgan (2009), Walking Away from Terrorism, p. 152; Neil Ferguson (2016), "Disengaging from Terrorism: A Northern Irish Experience," p. 2.

${ }^{33}$ I. E. Putra et al. (2018), "Tackling Islamic Terrorism and Radicalism in Indonesia by Increasing the Sense of Humanity and Friendship," in Handbook of Research on Examining Global Peace Making in the Digital Age, IGI International, p. 28.
} 
of a movement or group; awareness that the costs of follow-up are too high; re-establishing relations with individuals or networks outside the circle of jihad; family pressure; changing personal and professional priorities; and humane care by the authorities. ${ }^{34}$

The purpose of this study is to determine whether Islah can be applied to extraordinary crimes of terrorism especially in Indonesia's context. Also, the authors would like to recommend how the implementation of Islah has succeeded in making the perpetrators of extraordinary crimes of terrorism realize their mistakes so far. Islam is also a culture, so Islam is everything that encompasses all human life or ways (attitudes) of life. ${ }^{35}$ Culture in Islam, among others, care (compassion), respect, responsible, integrity, and harmony (balance). ${ }^{36}$

\section{Result: Islah by Terrorism Bomb Victims with Perpetrators, Their Families and Networks in Indonesia}

In a terrorism case in Indonesia, the Islah method was first held by the Badan Nasional Penangulangan Terorisme (BNPT). In collaboration with NGOs, BNPT organized "The Gathering between Perpetrators and Families with Victims of Terrorism." It held at Wisma Makara Universitas Indonesia on July 14, 2011. There were 100 participants from perpetrators and families. There were three terrorism bomb victims and four religious leaders there, besides several stakeholders and facilitators also attending the gathering. This activity was successful even though the atmosphere at the beginning seemed uncomfortable. Forgiveness or reconciliation between the perpetrator and the victim resulted. The victims forgive the perpetrators, and the perpetrators admitted their mistakes and apologized to the victims. ${ }^{37}$

Furthermore, in 2011-2015, the Research Centre for Police Science Universitas Indonesia (PRIK-UI) under the leadership of Prof. Sarwono Wirawan Sarlito organized the Da'wah and Economic Empowerment Program for Former Terrorism and Their Networks event. Overall, Islah between the terrorist and the victim has been successful. Based on observations during the implementation of Islah: all former terrorists and associates look enthusiastic and listened seriously; no one moved from their seats; after the victims of the terrorism had finished their speaking, most participants expressed their apologies, acknowledged their mistakes, and were willing to help if needed; the participants came to the victims to shake hands and hug; at the end of the discussion, former terrorists and victims spoke together informally, laughing together and taking photographs together. This shows that former terrorists and victims have established emotional closeness. However, the implementation of reconciliation in Poso did not run optimally. This is because ex-convicts and their networks in Poso also categorized themselves victims.

The response to Islah's success can be seen in the opinions and comments of terrorists as follows: a participant in Jakarta admitted that excitement disappeared when he met the bomb victim. He felt embarrassed for his friend's actions and would like to make up for them. ${ }^{38} \mathrm{~A}$ participant in Bandung said, "In my opinion, this event became a meaningful learning for me. I agree with peace wishes. I also agree that Indonesia is a peaceful country that does not deserve to be a place / target for bombings. So, I suggest that jihad action is not appropriate in Indonesia because there are many disadvantages rather than benefits. ${ }^{\prime 39}$ All participants in Semarang were amazed by the source person's and his family's endurance in facing the tragedy. The participants also appreciated the source person's activeness in preventing terrorism actions by presenting and approaching former terrorism actors. ${ }^{40} \mathrm{~A}$ participant in Lamongan said, "If today I was planning a bomb and I met you first, then I would cancel it." ${ }^{41}$ Some

\footnotetext{
${ }^{34}$ Julie Chernov Hwang (2017), "The Disengagement of Indonesia Jihadists: Understanding the Pathways," Terrorism and Political Violence, Vol. 29, no. 2, pp. 1-19.

${ }^{35}$ Widyastini (2004), "Nilai-Nilai Islam Dalam Kebudayaan Indonesia (Kajian Filsafat Nilai)," Jurnal Filsafat, Vol. 14, no. 2 , p. 122.

${ }^{36}$ Mukhibat (2014), "Reinventing Nilai-Nilai Islam, Budaya, dan Pancasila dalam Pengembangan Pendidikan Karakter," Jurnal Pendidikan Islam, Vol. 1, no. 2, p. 253.

${ }^{37}$ S.W. Sarwono (2012), Terrorism in Indonesia: In a Psychological Review, Jakarta: Alvabet, pp. 139-160.

${ }^{38}$ S. W. Sarwono et al. (2013), Post Prison Report: Jakarta and Bandung, Pusat Riset Ilmu Kepolisian Universitas Indonesia, p. 28.

${ }^{39}$ Sapto Priyanto \& Danamasi O. D. (2015), Impact of Terrorism on Innocent Bystanders Workshop in Bandung, Pusat Riset Ilmu Kepolisian Universitas Indonesia, p. 6.

${ }^{40}$ S. W. Sarwono et al. (2013), Post Prison Report: Semarang and Surabaya, Pusat Riset Ilmu Kepolisian Universitas Indonesia, p. 10.

${ }^{41}$ S. W. Sarwono et al. (2013), Post Prison Report: Semarang and Surabaya, p. 10; S. W. Sarwono et al. (2013), Post Prison Report: Jakarta and Bandung, p. 24.
} 
participants in Lampung initially interested and showed empathy with what happened to the speakers. ${ }^{42}$ Some participants in Poso said, "what happened to Febby as a victim of the terrorism bomb at the JW Marriot Hotel is different from what happened in Poso. In Poso, we became indirect victims and saw how the massacre of our family and relatives was killed by a Christian group. We became the perpetrators of the conflict because of attacks from Christian groups. The violence that occurs is an attempt to defend themselves." "I also feel sorry for what happened to Febby, but what happened in Poso is also terrible." "We are all victims, but the reaction is different. The difference is that Febby can forgive while we cannot just forget and forgive the perpetrators who attacked Poso."43

The success of the Islah program for former terrorist and their networks continued in terrorism prisoners in 2016-2017 by the Research Centre for Police Science and Terrorism Studies Universitas Indonesia (PRIK-KT UI). The implementation process of this activity was the same as the previous activity by former terrorists. The difference was only in the number of participants. This is because some of the ISIS members were not willing to participate ${ }^{44}$ possibly because in the applicable rules, the terrorism prisoners have the right to refuse to meet with people. This activity ran smoothly and successfully, including in Islah or reconciliation session. Only at the Salemba Penitentiary, all prisoners of terrorism (ISIS and Non-ISIS) take part in Islah activities, even though terrorist prisoners supporting ISIS seem uninterested but remain in the room until the activity ends.

Other proof of successful implementation of Islah can be seen from the statement by a terrorist prisoner who hid Noordin Muhamad Top as a fugitive of Detachment 88 at POLRI in Surabaya, East Java. While crying, he said "Saya mohon maaf atas kesalahan saya, saya tidak mengira kalau akan bertemu dengan korban yang ternyata muslim juga. Ini pernah saya tanyakan ke Noordin M Top, bagaimana jika ada muslim yang jadi korban? Namun tidak dijawab." 45 ["I apologize for my mistakes; I did not think that I would meet a Moslem as a victim. I once asked Noordin M. Top, what if there were Muslims who were victims? But he did not answer."'] Marwan also prayed for the victims of the bomb to get the best reward from God. ${ }^{46}$ Fadly understood the sadness experienced by the bomb victims and he also stated that the bomb incident in Indonesia violated the principles of the Islamic Religion. ${ }^{47}$ Agung responded that he was saddened by what was experienced by the victim. ${ }^{48}$

Now, the NGO institution that focuses on the reconciliation between victims and former terrorist or terrorism prisoners is Aliansi Indonesia Damai (AIDA). AIDA and BNPT held "Silaturahmi Kebangsaan Negara Kesatuan Republik Indonesia (Satukan NKRI)" at the Borobudur Hotel, Jakarta on February 28,2018 . This activity attended by 124 former terrorist and 51 victims. This activity runs smoothly. ${ }^{49}$ In addition, AIDA facilitates the meeting of victims and their families with terrorists: Ali Imron, one of the 2002 Bali Bombers, asked to apologize to Aris Munandar's wife and child as the victims killed in the incident. This happened when Aris Munandar's wife and child visited Ali Imron in the Rutan Narkoba Polda Metro Jaya. ${ }^{50}$ Ahmad Hasan, one of the bombers in front of the Australian Embassy in Jakarta, admitted his mistake for lack of religious knowledge and asked to apologize to Iwan and his children as victims. Ahmad Hasan claimed that he felt regret after made a mistake. He hoped Iwan's children would forgive him. In the previous meeting Ahmad Hasan had asked for "qisas" by Iwan. Ahmad Hasan offered Iwan to take his eyes as retaliation for what Iwan had suffered with one

\footnotetext{
${ }^{42}$ Yuslikha K. W \& Dimas Okto Danamasi (2014), Impact of Terrorism on Innocent Bystanders Workshop, Post Prison Program, Pusat Riset Ilmu Kepolisian dan Kajian Terorisme, Lampung, 24 April 2014, p. 2.

${ }^{43}$ Yuslikha K. W \& Dimas Okto Danamasi (2014), Impact of Terrorism on Innocent Bystanders, p. 3.

${ }^{44}$ Pro ISIS terrorist prisoners are prisoners who support or become ISIS followers led by Al Bagdadi. Most ISIS Prisoners do not want to participate in Penitentiary and do not pray at the Penitentiary Mosque, but their congregational prayers are only with their groups. Terrorist convicts Counter ISIS, are prisoners who do not support and are not followers of ISIS. ISIS Counter Prisoners want to participate in Penitentiary activities and want to pray in congregation at the Penitentiary Mosquen.

${ }^{45}$ Sapto Priyanto (2017), Impact of Terrorism on Innocent Bystanders Workshop at Lapas Makassar, February 2, 2017, in Prison Re-education Program, Pusat Riset Ilmu Kepolisian dan Kajian Terorisme Universitas Indonesia, p. 3.

${ }^{46}$ Sapto Priyanto \& Fajar Erikha (2017), Impact of Terrorism on Innocent Bystanders Workshop at Lapas Pasir Putih, February 8, 2017, in Prison Re-education Program, Pusat Riset Ilmu Kepolisian dan Kajian Terorisme Universitas Indonesia, p. 3.

${ }^{47}$ Sapto Priyanto \& Vici Sofiana Putera (2016), Impact of Terrorism on Innocent Bystanders Workshop at Lapas Salemba, December 19, 2016, in Prison Re-education Program, Pusat Riset Ilmu Kepolisian dan Kajian Terorisme Universitas Indonesia, p. 4.

${ }^{48}$ Sapto Priyanto \& Vici Sofiana Putera (2017), Impact of Terrorism on Innocent Bystanders Workshop at Lapas Madiun, January 31, 2017, in Prison Re-education Program, Pusat Riset Ilmu Kepolisian dan Kajian Terorisme Universitas Indonesia, p. 4.

${ }^{49}$ Muhammad Gustirha Yunas (2018), “Lupakan Kenangan Buruk, BNPT Gelar Silaturahmi Kebangsaan,” Liputan 6, accessed April 26 2020, https://www.liputan6.com/news/read/3332024/lupakan-kenangan-buruk-bnpt-gelar-silaturahmi-kebangsaan\#.

${ }^{50}$ Muslimah (2020), "Garil Anak Korban Bom Bali I Bertemu Ali Imron Pelaku Pengeboman, Satu Pertanyaan Ini yang Diajukan," Tribun Bayumas, accessed April 26 2020, https://banyumas.tribunnews.com/2020/02/18/garil-anak-korban-bom-bali-i-bertemu-ali-imron-pelakupengeboman-satu-pertanyaan-ini-yang-diajukan?page=all.
} 
blind eye. However, with great and pure heart Iwan said that his arrival was not to demand revenge but to befriend him because Ahmad Hasan and Iwan were fellow Muslims. ${ }^{51}$

\section{Analysis and Discussion}

As the author has said above that Islah or reconciliation or restorative justice so far has only been done on ordinary crimes and the author has not found a reference to discuss it for the crime of terrorism. This is what distinguishes this research from previous studies. There are many methods of dealing with terrorists, but the author concludes that Islah is the most effective method. It can be seen from the observation above. The observation shows that Islah or reconciliation or peace or restorative justice implemented by terrorism victims to the terrorist in prison or former terrorist and their network in Indonesia.

The key to success of Islah's on terrorism cases in Indonesia because most victims of acts of terrorism in Indonesia finally accepted with sincerity that what happened to him was the destiny of God. Illness will make life more meaningful. This can be illustrated from the following statement of terrorism bomb victims: "Through the tragedy of the bomb I became more sincere in living my life. This is God's will, this is His love, I must be sincere, I must accept." "Allah Almighty gives trials will not exceed the limits of the ability of His servants. Each disaster actually contains learning (ibroh), for those who are steadfast and patient in all His will." "It "It faith that awakens our hearts. All is by the will of God; it is impossible for God to give a test beyond the limits of ability." "We forgive what they did so as not to do it again and speak for peace. There is no need for revenge because revenge will not bring the dead back to life. Forgiveness is better, because revenge will never return something." 54 "A person's faith goes up and down, so what the terrorist perpetrators do is a mistake. If we make peace with ourselves, we will automatically forgive whatever has hurt us." 55 "Violence must not be responded with violence." "Begin peace with yourself, and forgive the offender for a better life."

The strengths of the implementation of Islah in Indonesia are Ali Imron and Umar Patek who are figures among terrorists in Indonesia. When they are met with the victims, they also cannot hold their feelings of sadness, apologize, and admit their mistakes. According to Tony Soemarno who had met with Umar Patek while still being held at Mako Brimob Kelapa Dua Depok, West Java, Umar Patek sends his greetings to the other victims to forgive, Umar Patek is very worried if the victim and his family do not want to forgive.$^{57}$ Likewise with Ali Imron who apologized to the victim's child and his wife who came to see him. These two figures can have a positive impact on the implementation of Islah as a method of disengagement.

Islah is very important because it not only makes terrorists aware of their mistakes, but also makes them not become recidivism. The evidence that Islah succeeded as a method of disengagement in Indonesia is that of the 145 ex-terrorist convicts who took part in a program organized by PRIK UI during 20112015, only two people were involved. ${ }^{58}$ While the implementation of Islah carried out by PRIK KTUI in a number of penitentiary institutions with sixty-one terrorist prisoners, only one person was involved again as a recidivist.

Another strength of Islah, is that Islah is the culture of Indonesian society in solving problems and conflicts including criminal problems. Islah has been around since the Majapahit Kingdom. The Sasak people in Lombok, West Nusa Tenggara, have a dominant culture of peace and harmony known as the

\footnotetext{
${ }^{51}$ Endang Nurdin (2020), "Mengapa saya maafkan pelaku pengeboman: 'Dia menggigil, minta maaf, dan bilang kisas, ambil mata saya, saya rela dieksekusi," BBC News Indonesia, accessed March 11, 2020, https://www.bbc.com/indonesia/indonesia-50408539.

52 N. Permana (2019), "Jadi Korban Bom Teroris, Nurman Permana, Bangkit dan Ikhlas," AIDA, accessed December 6, 2019, https://www.aida.or.id/2019/11/6056/.

53 Ramdhani (2019), “Ketabahan Ramdhani Di Balik Musibah Bom Kuningan,” AIDA, accessed December 6, 2019, https://www.aida.or.id/2019/11/6007/.

54 Eka Laksmi (2019), "Eka Laksmi, Ketangguhan Istri Korban Terorisme," AIDA, accessed December 6, 2019, https://www.aida.or.id/2019/10/5790/.

55 Jihan (2019), "Penyintas Bom Kampung Melayu: Saya Bangkit Demi Ibu," AIDA, accessed December 6, 2019, https://www.aida.or.id/2019/11/6022.

${ }_{56}^{56}$ Sudjarwo (2019), "Sudjarwo Bangkit Kembali Merajut Mimpi," AIDA, accessed December 6, 2019, https://www.aida.or.id/2019/11/5941/.

${ }^{57}$ Anwar Khumaini (2014), "Kisah persahabatan Umar Patek dengan korban bom Hotel JW Marriot," Merdeka.com, accessed April 22, 2020, https://www.merdeka.com/peristiwa/kisah-persahabatan-umar-patek-dengan-korban-bom-hotel-jw-marriot.html.

${ }_{58}$ Anwar Khumaini (2014), "Kisah persahabatan Umar Patek dengan korban bom Hotel JW Marriot.”; Putra et al. (2018), “Tackling Islamic Terrorism and Radicalism in Indonesia,” p. 29.
} 
ajinin concept. Ajini means mutual respect, remorse, friendship, regen which means giving, choosing a safe situation of peace and supporting the tolerance of the people of Lombok in undergoing social relations. ${ }^{59}$ The Dayak Selakau Kanaytn Kalimantan community implements local wisdom in resolving conflicts with Pamabakng. Pamabakng is an effort to solve the problem by submitting to God, which is done by carrying out traditional rituals. Also done with Bahaump. Bahaump is often familiar with deliberation. ${ }^{60}$ The people of Aceh have cultural values such as di'iet and suloh which originate from Islamic teachings. The di'iet culture originates from diyat and the sulul culture comes from reconciliation. This diyat refers to the holy book Al-Qur'an verses Al-Baqarah (2): 178, while al-Islah in the QS. Al-Hujurat (49): 10. ${ }^{61}$ Ambonese people recognize "pela gadong" as a harmonization of life that has existed for a long time and is the key to resolving conflicts in Ambon. ${ }^{62}$ Community leaders are also still the key to resolving conflicts in Tulungagung, East Java. ${ }^{63}$

Islah's weaknesses in Indonesia include that this approach did not become the main program for BNPT, Nahdatul Ulama (NU) and Muhammadiyah in counteracting radicalism and terrorism. Even though NU actually thinks of the concept of tolerance in moderating extreme views, according to As'ad Said Ali, the NU Program in counteracting radicalism and terrorism only covers three things, namely preaching, social activities, and economic empowerment. ${ }^{64}$

While Muhammadiyah was even negatively affected by terrorism radicalism because some perpetrators allegedly had closeness with Muhammadiyah. This got a serious response from Muhammadiyah who stated that it was an Islamic movement that carried its identity as a moderate Islam. ${ }^{65}$ Muhammadiyah is also the same as NU's view and attitude towards the need for tolerance and harmony among religious believers. In its program Muhammadiyah invites Muslims, especially Persyarikatan citizens, to be critical by trying to stem the development of takfiri groups (groups of infidels of different groups) through a dialogue approach, open propaganda, enlightening, and polite social interaction. However, Islah also has not become one of the programs for Muhammadiyah. ${ }^{66}$

Another weakness is that only a handful of terrorists supporting ISIS are willing to take part in Islah activities when carried out in a penitentiary. based on the author's experience, Islah is not easy to do. Patience and caution are needed in carrying out Islah.

Islah implementation is a process, not an event ${ }^{67}$ Islah cannot be carried out suddenly, but it requires a long process to be carried out properly. The Islah process that the author has done includes planning, forming a team, establish victims of terrorism, establish terrorists, establish facilitators and resource persons, establish stakeholders and adequate funding. The implementation team should be someone who has experience in handling conflicts and has good relations with terrorists and victims, otherwise the process will be longer. Islah not only took place during the process of meeting between victims of terrorism and the perpetrators, but continued with friendly relations (silaturahim).

\section{Conclusion}

Based on the novelty, the authors can conclude that Islah as a method of disengagement for terrorism in Indonesia has proven to be well implemented. This can be seen from the responses of the participants (perpetrators) who mostly focused on listening to the explanation of the victims of terrorism bombs, see the film of the profile of the terrorism bomb victim's association in Indonesia and expressed their condolences over the suffering that was experienced by the speakers (terrorism victims).

\footnotetext{
${ }^{59}$ Suprapto (2013), "Revitalisasi Nilai-Nilai Kearifan Lokal Bagi Upaya Resolusi Konflik,” Walisongo, Vol. 21 , no. 1, p. 33.

${ }^{60}$ Muzammilul Abrori (2017), "Kearifan Lokal Suku Dayak Dalam Penyelesaian Konflik,” Tribun Pontianak, accessed April 21,2020, https://pontianak.tribunnews.com/2017/11/17/kearifan-lokal-suku-dayak-dalam-penyelesaian-konflik.

${ }^{61}$ Chaerol Riezal, Hermanu Joebagio \& Susanto (2018), "Revitalisasi Kearifan Lokal Aceh: Gagasan Islam dan Budaya dalam Menyelesaikan Konflik di Masyarakat, Millatī," Journal of Islamic Studies and Humanities, Vol. 3, no. 2, p. 233.

${ }^{62}$ Hendry Bakri (2015), "Conflict Resolution toward Local Wisdom Approach of Pela Gandong in Ambon City," The POLITICS: Jurnal Magister Ilmu Politik Universitas Hasanuddin, Vol. 1, no. 1, pp. 52-53.

${ }^{63}$ M. G. Bagus Ani Putra (2013), "The role of local wisdom for religions conflict resolution in East Java, Masyarakat," Kebudayaan dan Politik, Vol. 26, no. 1, p. 13.

64 As'as Said Ali (2015), “Peran NU Dalam Menangkal Radikalisme,” NU Online, accessed April 21, 2020, https://www.nu.or.id/post/read/58396/peran-nu-dalam-menangkal-radikalisme.

${ }^{65}$ Zuly Qodir \& Saefudin Zuhri (2017), "Muhammadiyah \& Fenomena Radikalisme-Terorisme di Indonesia," MAARIF, Vol. 12, no. 1, p. 4.

${ }^{66}$ Zuly Qodir \& Saefudin Zuhri (2017), “Muhammadiyah \& Fenomena Radikalisme-Terorisme di Indonesia,” p. 6.

${ }^{67}$ N. Riestenberg (2015), The Restorative Implementation: Paradigms and Practice, Restorative Practices in Action Journal: For School and Justice Practitioners, New York: New York State Permanent Judicial Commission on Justice for Children, p. 4.
} 
The author agrees with Walgrave, ${ }^{68}$ that restorative justice (Islah) will be carried out well because there is a match between the victim and protection. The compatibility is that victims who are met with perpetrators are indeed victims of acts of terrorism committed by perpetrators. Islah has an optimal effect if the participants come from conflict areas such Poso, because they are also victims. In Indonesia this Islah roots in the people culture. Anthropological studies explain this phenomenon as social culture of Indonesian. People in Indonesia intent to forgive things that happened to them as their fate, as nothing they can do to change their fate that was given by God. This phenomenon also roots in Islamic morals, the concept of Jabariya explain that everything happened is nothing but God's will, impact of this religious culture and understanding in Indonesia is victims of terrorist attack who seeks religious answer of what happened to them will find out that the only solution is to forgive and wait for the final judgment in akhirah, the afterlife or judgment by God.

Establishing good relations with ex-convicts and their networks has an important role in their voluntary presence. Understanding and adjusting the values that apply to ex-convicts and their networks make it easy to communicate and process Islah. Islah is the first time a former terrorism convict and his network participated in an activity carried out by an institute outside his group (academics), so that at the beginning of the Islah, some participants tended to be passive and impressed observing the situation. After the Islah has been running for some time, the ex-convicts and the network look comfortable. The available Islah room is not possible to be set as expected in a circular shape in several locations making the Islah process less optimal (equally important). That involve ex-convicted terrorists and their networks to convey that the documentation of activities is only for a limited circle and not publicized. This will make the participants more comfortable.

Some stages needed in process to implement Islah or reconciliation or restorative justice. These are (1) choose the selected victims who have truly forgiven the terrorist, have no resentment at all, looks simple and want to meet with terrorists, (2) hold a Trainer for Trainer for all people and institutions that involved in Islah or reconciliation activities to equalize the vision, mission, goals, and implementation, (3) choose the selected terrorists for selected victim, (4) prepare the comfortable room and place settings to make all participant feel comfort, including the sitting position, it should be circular, (5) understand the norms applied among terrorists in Indonesia, such as using the common "Arabic language" such as "antum" to refer the terrorist, and (6) ensure stakeholders will be consistently friendly.

\section{References}

Abrori, M (2017), "Kearifan Lokal Suku Dayak Dalam Penyelesaian Konflik," Tribun Pontianak, accessed April 21, 2020, https://pontianak.tribunnews.com/2017/11/17/kearifan-lokal-suku-dayakdalam-penyelesaian-konflik.

Ali, S. A. (2015), "Peran NU Dalam Menangkal Radikalisme," NU Online, accessed April 21, 2020, https://www.nu.or.id/post/read/58396/peran-nu-dalam-menangkal-radikalisme.

Septianto, B. (2019), "Kapolri Klaim Jumlah Aksi Terorisme Sepanjang 2019 Berkurang," accessed March 7, 2020, https://tirto.id/ellv.

Bakri, H. (2015), "Conflict Resolution toward Local Wisdom Approach of Pela Gandong in Ambon City,” The POLITICS: Jurnal Magister Ilmu Politik Universitas Hasanuddin, Vol. 1, no. 1.

Bertjan et al. (2016), "Terrorism, Radicalization and De-radicalization," Current Opinion in Psychology, Vol. 11.

Blueprint Deradicalization (2013), Deputy for Prevention, Protection and Deradicalization of the National Counterterrorism Agency. ${ }^{68}$ L. Walgrave (2011), “Investigating the Potentials of Restorative Justice Practice," Washington University Journal of Law \& Policy, Vol.
36, p. 98 . 
Journal of Al-Tamaddun, Vol. 15 (1), 2020, 157-168

Miers, D. (2001), An International Review of Restorative Justice, Crime Reduction Research Series Paper 10, London: Home Office Policing and Reducing Crime Unit Research, Development and Statistics Directorate Clive House.

Ferguson, N. (2016), "Disengaging from Terrorism: A Northern Irish Experience," Journal for Deradicalization, Vol. 6, no. 1.

Fitriani, Y. \& Agung, M. I. (2018), "Islamic Religiosity and Humility with Forgiveness of Students," Psychology Journal, Vol. 14, no. 2.

Shewan, G. (2011), Restorative Justice Guidance and Minimums Standards, Association of Chief Police Officers of England.

Hoffman, B. (2009), "A counterterrorism strategy for the Obama administration," Terrorism and Political Violence, Vol. 21, no. 3.

Horgan, J. (2008), "Deradicalization or Disengagement? A Process in Need of Clarity and a Counterterrorism Initiative in Need of Evaluation," Perspectives on Terrorism, Vol. 2, no. 4.

Horgan, J. \& Altier, M. B. (2012), "The Future of Terrorist De-Radicalization Programs," Conflict \& Security Journal, Vol. 13, no. 2.

Horgan, J. \& Braddock, K. (2010), Rehabilitating the Terrorist? Challenges in Assessing the Effectiveness of De-radicalization Program, University Park, Pennsylvania: International Center for Study of Terrorism, Pennsylvania State University.

Horgan, J. (2009), Walking Away from Terrorism: Accounts of Disengagement from Radical and Extremist Movements, New York: Routledge.

Hwang. J. C. (2017), "The Disengagement of Indonesia Jihadists: Understanding the Pathways," Terrorism and Political Violence, Vol. 29, no. 2.

Ikhwan (2011), "Penyelesaian Kasus Pelanggaran Ham Pada Masa Rasulullah Saw," Miqot, Vol. 35, no. 2 .

Institute for Economics \& Peace (2019), Global Terrorism Index 2019: Measuring the Impact of Terrorism, accessed March 10, 2020, http://visionofhumanity.org/reports.

Interview with Deradicalization Director of National Counter Terrorism Agency (BNPT), May 15, 2018.

Jihan (2019), "Penyintas Bom Kampung Melayu: Saya Bangkit Demi Ibu," AIDA, accessed December 6, 2019, https://www.aida.or.id/2019/11/6022.

Jumala, N. \& Abubakar (2019), "Internalisasi Nilai-Nilai Spiritual Islami Dalam Kegiatan Pendidikan," Jurnal Serambi Ilmu, Vol. 20, no. 1.

Khumaini, A. (2014), "Kisah persahabatan Umar Patek dengan korban bom Hotel JW Marriot," Merdeka.com, accessed April 22, 2020, https://www.merdeka.com/peristiwa/kisah-persahabatan-umarpatek-dengan-korban-bom-hotel-jw-marriot.html.

Koehler, D. \& Fiebig, V. (2019), "Knowing What to Do: Academic and Practitioner Understanding of How to Counter Violent Radicalization," Perspectives on Terrorism, Vol. 13, no. 3.

Laksmi, E. (2019), "Eka Laksmi, Ketangguhan Istri Korban Terorisme," AIDA, accessed December 6, 2019, https://www.aida.or.id/2019/10/5790/. 
Umbreit, M. S. \& Lewis, T. (2015), Dialogue-Driven Victim-Offender Mediation Training Manual A Composite Collection of Training Resource Materials, University of Minnesota Center for Restorative Justice \& Peacemaking.

Mufid, S. A. et al. (2012), Motivation and The Roots Causes of Terrorism in Indonesia, ASEAN and Egypt, Resume Research Report.

Mukhibat (2014), "Reinventing Nilai-Nilai Islam, Budaya, dan Pancasila dalam Pengembangan Pendidikan Karakter," Jurnal Pendidikan Islam, Vol. 1, no. 2.

Muslimah (2020), "Garil Anak Korban Bom Bali I Bertemu Ali Imron Pelaku Pengeboman, Satu Pertanyaan Ini yang Diajukan," Tribun Bayumas, accessed April 262020 , https://banyumas.tribunnews.com/2020/02/18/garil-anak-korban-bom-bali-i-bertemu-ali-imronpelaku-pengeboman-satu-pertanyaan-ini-yang-diajukan?page=all.

Mustafa, C. (2015), "Restorative Justice and Islam," ResearchGate, accessed March 10, 2020, https://doi.org/10.13140/RG.2.1.3135.6883.

Nurdin, E. (2020), "Mengapa saya maafkan pelaku pengeboman: 'Dia menggigil, minta maaf, dan bilang kisas, ambil mata saya, saya rela dieksekusi," BBC News Indonesia, accessed March 11, 2020, https://www.bbc.com/indonesia/indonesia-50408539.

Pavelka, S. (2016), "Restorative Justice in the States: An Analysis of Statutory Legislation and Policy," Justice Policy Journal, Vol. 2, no. 13.

Permana, N. (2019), “Jadi Korban Bom Teroris, Nurman Permana, Bangkit dan Ikhlas,” AIDA, accessed December 6, 2019, https://www.aida.or.id/2019/11/6056/.

Priyanto, S. \& Danamasi O. D. (2015), Impact of Terrorism on Innocent Bystanders Workshop in Bandung, Pusat Riset Ilmu Kepolisian Universitas Indonesia.

Priyanto, S. \& Erikha, F. (2017), Impact of Terrorism on Innocent Bystanders Workshop at Lapas Pasir Putih, February 8, 2017, in Prison Re-education Program, Pusat Riset Ilmu Kepolisian dan Kajian Terorisme Universitas Indonesia.

Priyanto, S. \& Putera, V. S. (2016), Impact of Terrorism on Innocent Bystanders Workshop at Lapas Salemba, December 19, 2016, in Prison Re-education Program, Pusat Riset Ilmu Kepolisian dan Kajian Terorisme Universitas Indonesia.

Priyanto, S. \& Putera, V. S. (2017), Impact of Terrorism on Innocent Bystanders Workshop at Lapas Madiun, January 31, 2017, in Prison Re-education Program, Pusat Riset Ilmu Kepolisian dan Kajian Terorisme Universitas Indonesia.

Priyanto, S. (2017), Impact of Terrorism on Innocent Bystanders Workshop at Lapas Makassar, February 2, 2017, in Prison Re-education Program, Pusat Riset Ilmu Kepolisian dan Kajian Terorisme Universitas Indonesia.

Putra, E. I., Danamasi O. D., Rufaedah A., Arimbi S. R. \& Priyanto, S. (2018), "Tackling Islamic Terrorism and Radicalism in Indonesia by Increasing the Sense of Humanity and Friendship," in Handbook of Research on Examining Global Peace Making in the Digital Age, IGI International.

Putra, A. B. G. M. (2013), "The role of local wisdom for religions conflict resolution in East Java, Masyarakat," Kebudayaan dan Politik, Vol. 26, no. 1.

Qodir, Z. \& Zuhri, S. (2017), "Muhammadiyah \& Fenomena Radikalisme-Terorisme di Indonesia," MAARIF, Vol. 12, no. 1. 
Ramdhani (2019), "Ketabahan Ramdhani Di Balik Musibah Bom Kuningan," AIDA, accessed December 6, 2019, https://www.aida.or.id/2019/11/6007/.

Riestenberg, N. (2015), The Restorative Implementation: Paradigms and Practice, Restorative Practices in Action Journal: For School and Justice Practitioners, New York: New York State Permanent Judicial Commission on Justice for Children.

Riezal, C., Hermanu, J. \& Susanto (2018), "Revitalisasi Kearifan Lokal Aceh: Gagasan Islam dan Budaya dalam Menyelesaikan Konflik di Masyarakat, Millatī," Journal of Islamic Studies and Humanities, Vol. 3, no. 2.

Sarwono, S. W. (2012), Terrorism in Indonesia: In a Psychological Review, Jakarta: Alvabet.

Sarwono, S. W. et al. (2013), Post Prison Report: Jakarta and Bandung, Pusat Riset Ilmu Kepolisian Universitas Indonesia.

Sarwono, S. W. et al. (2013), Post Prison Report: Semarang and Surabaya, Pusat Riset Ilmu Kepolisian Universitas Indonesia.

Sudjarwo (2019), "Sudjarwo Bangkit Kembali Merajut Mimpi," AIDA, accessed December 6, 2019, https://www.aida.or.id/2019/11/5941/.

Sumpter, C., Wardhani, K. Y. \& Priyanto, S. (2019), Testing Transitions: Extremist Prisoners ReEntering Indonesian Society, New York: Routledge.

Suprapto (2013), "Revitalisasi Nilai-Nilai Kearifan Lokal Bagi Upaya Resolusi Konflik," Walisongo, Vol. 21, no. 1.

Van Ness, W. D. (2005), An Overview of Restorative Justice Around the World, Centre for Justice \& Reconciliation Prison Fellowship International.

Wachtel, T. (2013), Defining Restorative, International Institute for Restorative Practices.

Walgrave, L. (2011), "Investigating the Potentials of Restorative Justice Practice," Washington University Journal of Law \& Policy, Vol. 36.

Widyastini (2004), "Nilai-Nilai Islam Dalam Kebudayaan Indonesia (Kajian Filsafat Nilai)," Jurnal Filsafat, Vol. 14, no. 2.

Yunas, M. G. (2018), "Lupakan Kenangan Buruk, BNPT Gelar Silaturahmi Kebangsaan," Liputan 6, accessed April 26 2020, https://www.liputan6.com/news/read/3332024/lupakan-kenangan-buruk-bnptgelar-silaturahmi-kebangsaan\#.

Zulfa, A. E. (2011), "Restorative Justice in Indonesia: Traditional Value," Indonesia Law Review, Vol. 2 , no. 1 . 